\title{
Wewenang KPPU terhadap Pemberian Sanksi pada Pihak Lain Dalam Kasus Persekongkolan Tender
}

\author{
Nurul Fitriani \\ Universitas Negeri Airlangga Surabaya \\ Kampus B Jl. Dharmawangsa Dalam Selatan Surabaya, Kode Pos. 60286 \\ Correspondence email: nurul.fitriani-2018@ fh.unair.ac.id
}

\begin{abstract}
Abstrak. Persaingan usaha tidak sehat akan menyebabkan kerugian terhadap konsumen maupun terhadap pelaku usaha, praktik dunia usaha yang tidak sehat pula akan merusak stabilitas ekonomi nasional yang dapat menyebabkan terjadinya krisis moneter dalam suatu negara. Lahirnya Undang-Undang Nomor 5 Tahun 1999 merupakan upaya mencegah praktik persaingan usaha tidak sehat, terlebih di dalam penyelenggaran tender pengadaan barang dan/atau jasa. Sehingga sangatlah menarik permasalahan dalam penelitian ini yang mengambil pendekatan yuridis terhadap kasus persengkongkolan tender serta wewenang KPPU dalam memberikan sanksi terhadap pihak yang melakukan usaha curang dalam penyelenggaraan tender, dan terkait masalah ketiadaan sanksi bagi pihak lain yaitu panitia/ penyelenggara tender atau pun pejabat pemerintah serta politikus yang terlibat dalam persekongkolan tender. Penelitian ini menggunakan metode penelitian Yuridis Normatif dengan menggunakan sumber data sekunder melalui studi kepustakaan yang di analisis secara deskriptif kualitatif. Hasil penelitian di dapati bahwa persekongkolan dalam penyelenggaran tender dapat terjadi secara horizontal maupun vertical, sehingga pendekatan yuridis dalam hal ini sangat lah cocok digunakan guna menjerat para pelaku usaha tidak sehat, pendekatan yuridis yang digunakan adalah pendekatan per se ilegal. Dalam Undang-Undang Nomor 5 Tahun 1999 telah memeberikan wewenang kepada KPPU untuk memberi sanksi terhadap para pelaku praktik usaha tidak sehat, surat keputusan yang dikeluarkan oleh KPPU merupakan keputusan yang berkekutan hukum (legal), akan tetapi wewenang KPPU dalam menjatuhkan sanksi terhadap pelaku praktik usaha tidak sehat itu hanya sebatas sanksi administrasi.
\end{abstract}

Kata kunci: Persekongkolan; Tender; Monopoli

Abstract. Unfair business competition will cause losses to consumers and business parties, unhealthy business practices will also damage national economic stability, which can lead to a monetary crisis in a country. The raise of Regulation Number 5 of 1999 is an effort to prevent unfair business competition practices, especially in organizing tenders for the procurement of goods and $/$ or services. So it is very interesting that the problem in this research is that it takes a juridical approach to cases of tender conspiracy and the authority of the KPPU in imposing sanctions on parties who commit fraudulent efforts in holding tenders, and related to the problem of the absence of sanctions for other parties, namely the committee / tender organizer or government officials and politicians. involved in tender rigging. This study uses the juridical normative research method using secondary data sources through literature studies which are analyzed qualitatively descriptive. The research found that conspiracy in the holding of tenders can occur horizontally or vertically, so that the juridical approach in this case is very suitable to be used to ensnare unhealthy business actors, the juridical approach used is the per se illegal approach. Law Number 5 of 1999 has given the authority to KPPU to impose sanctions on perpetrators of unhealthy business practices, decisions issued by KPPU are legal decisions, however KPPU has the authority to impose sanctions on business practice actors. unhealthy is only limited to administrative sanctions.

Keywords: Confederacy; Tender; Monopoly

\section{PENDAHULUAN}

Persaingan merupakan aktivitas yang dilakukan manusia dalam bentuk usaha untuk saling mengungguli satu sama lain. Dalam satu sisi persaingan memiliki dampak positif untuk meningkatkan motivasi dalam berinovasi dan meningkatkan kualitas pribadi maupun produktifitas. Dalam dunia bisnis persaingan memiliki sisi lain yang negatif dengan tujuan penguasaan pasar maupun meningkatkan penjualan secara signifikan yang menyebabkan para pelaku usaha menghalalkan segala cara dalam bersaing dengan pelaku usaha lainnya.

Persaingan usaha tidak sehat dapat menyebabkan kerugian baik bagi konsumen maupun pelaku usaha lain yang bergerak dalam suatu bisnis dan pasar yang sama. Selain itu dampak besar dari iklim usaha yang tidak sehat juga dapat merusak kestabilitasan ekonomi nasional hingga terjadinya krisis moneter dalam suatu negara. Contoh nyata dalam hal ini ialah terjadinya puncak krisis moneter di Indonesia pada tahun 1998. Dalam rangka membatasi krisis moneter yang telah dasyat melanda dan menjadikan ekonomi Indonesia terpuruk secara luas, negara mengajukan kredit pada IMF. Lahirnya Undang-Undang Nomor 5 Tahun 1999 merupakan desakan dari IMF serta salah satu konsekwensi dari peratifikasian perjanjian Marrakesh oleh DPR dengan Undang-Undang Nomor 7 Tahun 1974 yang mengharuskan Indonesia membuka diri dan tidak boleh memberikan perlakuan diskriminatif, diantaranya 
dengan memberikan perlindungan terhadap entrie barrier bagi suatu perusahaan. ${ }^{1}$

Menurut Ahmad Yani dan Gunawan Widjaja dalam bukunya yang berjudul Seri Hukum Bisnis Anti Monopoli, yang kemudian dikutip oleh Supianto dalam jurnalnya berpendapat bahwa hadirnya peraturan mengenai larangan praktek monopoli di Indonesia terbilang telah jauh tertinggal bila dikomparasikan dengan negara-negara lainnya. Sebagai contoh, Amerika Serikat dalam mencegah dan mengantisipasi praktek monopoli, telah mengeluarkan beberapa regulasi dimulai dari The Sherman Act 1890, dilanjutkan dengan keluarnya regulasi The Clayton Antitrust Act 1914, The Faderal Trade Commission Act 1914 , Robinson Patman Act 1936, dan terakhir Celler-Kefauver Act 1950. Sedangkan di Jerman telah mengeluarkan regulasi serupa pada tahun 1909 yakni dengan adanya undangundang tentang Unfair Competition. Demikian pula dengan negara tetangga kita yakni Philipina yang telah membuat satu chapter khusus tentang Frauds in Commerce \& Trade pada Penal Code No 3815 yang telah mengalami revisi pada tahun $1930 .{ }^{2}$

Namun dengan adanya undang-undang Nomor 5 Tahun 1999 diharapkan melahirkan iklim persaingan yang sehat dan mencegah terjadinya praktik monopoli yang dilakukan oleh segenap pelaku usaha. Terlebih lagi dalam penyelenggaraan tender pengadaan barang dan/ atau jasa yang dilakukan oleh pemerintah, karena kaitannya dengan pemanfaatan keuangan negara baik APBN maupun APBD yang bertujuan menyejahterakan masyarakat. Sebagai pagar yang membatasi kecurangan pelaku usaha, pengaturan larangan persekongkolan tender diatur dalam Undang-Undang Nomor 18 Tahun 1999 tentang Jasa Konstruksi j.o Peraturan Pemerintah Nomor 29 Tahun 2000 tentang Penyelenggaraan Jasa Konstruksi. Selain itu juga diatur dalam pasal khusus pada Undang-Undang Nomor 5 Tahun 1999, tepatnya pada pasal $22 .{ }^{3}$

Secara terminologi, menurut Sudarsono dalam kamus hukumnya istilah tender dapat diartikan sebagai suatu kegiatan memborong pekerjaan atau menyuruh pihak lain untuk memborong ataupun mengerjakan suatu pekerjaan baik sebagian maupun seluruhnya sesuai dengan perjanjian yang telah dibuat. Sehingga secara umum tender meliputi : 1) Memborong atau melaksanakan suatu pekerjaan, 2) Menjual barang atau jasa, 3) Membeli barang atau jasa, 4) Mengadakan

\section{Adifyan Rahmat Asga dan Ditha Wiradiputra,}

"Analisa Kedudukan Panitia Tender Dalam Persekongkolan Tender Secara Vertikal (Studi Kasus Putusan KPPU Nomor 04/KPPU-L/2013)," Universitas Indonesia (2012): 2, hlm 2.

2 Supianto, "Pendekatan Per Se Illegal Dan Rule Of Reason Dalam Hukum Persaingan Usaha Di Indonesia," Jurnal Rechtens 2 (2013).

3 L Budi Kagramanto, "Komparasi Pengaturan Tender Di Indonesia Dan Jepang Dalam Prespektif Hukum Persaingan Usaha," Era Hukum (2007), hlm 656-657.. barang atau jasa. ${ }^{4}$ Dalam pengertian tersebut diketahui bahwa ender merupakan bentuk pekerjaan yang biasanya memakan biaya yang cukup tinggi karena sifatnya borongan atau dalam jumlah yang besar bukan satuan, sehingga banyak pelaku usaha yang berminat mengajukan lelang/ tender tersebut. Tiap pelaku usaha yang menjadi peserta tender memiliki kedudukan yang sama dalam mencapai kepentingannya. Karena tujuan dari tender ialah untuk memberikan kesempatan sama kepada semua peserta sehingga dapat menghasilkan harga lelang serendah mungkin dngan kualifikasi sebaik mungkin. 5

Jika tujuan dari pelaksana tender dalam kegiatan ini ialah untuk memperoleh kualias terbaik dengan harga terendah, maka lain halnya dengan prinsip para pelaku usaha yang menginginkan keuntungan tertinggi. Sehingga banyak pelaku usaha yang melakukan persekongkolan untuk memenangkan sebuah tender dengan melakukan permainan harga dan berpura-pura bersaing dengan rekan bisnisnya. Terbukti dari banyaknya putusan KPPU mengenai pelanggaran terhadap pasal 22 tetang larangan persekongkolan tender. Persekongkolan tender termasuk salah satu perbuatan yang dianggap merugikan negara, karena terdapat unsur manipulasi harga penawaran, dan cenderung menguntungkan pihak yang terlibat dalam persekongkolan.

Dari konsep-konsep tender yang sedemikian rupa telah diatur prosedur dan tata cara pelaksanaannya serta peraturan-peraturan yang memuat sanksi atas pelanggarannya, masih saja ada celah bagi pelaku usaha yang curang untuk melakukan persekongkolan tender. Contohnya pada kasus pembangunan pasar modern pada kota Prabumulih yang telah ditetapkan putusannya oleh KPPU pada tahun 2007 dengan nomor 15/KPPUL/2007. Sehingga penulis merumuskan permasalahan dalam penelitian ini adalah pendekatan yuridis terhadap kasus persekongkolan tender serta wewenang KPPU dalam memberikan sanksi terhadap pihak lain dalam persekongkolan tender.

\section{METODE}

Metode penelitian yang penulis lakukan dalam penelitian ini menggunakan pendekatan yuridis normatif, menurut Ronny Hanitidjo Soemitro penelitian ini digunakan untuk mengkaji dan menganalisis data sekunder yang berupa bahan-bahan hukum primer dan bahan hukum sekunder. Sepesifikasi yang digunakan adalah analisis deskriptif, dengan menggunakan metode pengumpul data dari sumber data sekunder melalui study

\footnotetext{
${ }^{4}$ Sudarsono, Kamus Hukum (Jakarta: Rineka Cipta 1992).

5 Enrico Billy Keintjem, "Tinjauan Yuridis Praktek Persekongkolan Yang Tidak Sehat Dalam Tender Proyek Menurut Undang-Undang Nomor 5 Tahun 1999," Lex Administrantum 4.4 (2016), hlm 104.
} 
library. Serta kemudian dianalisis menggunakan metode kualitatif.

\section{Tipe Penelitian}

Pada penelitian untuk penulisan proposal ini, penulis akan menggunakan jenis penelitian normatif. Penelitian ini dilakukan atau ditujukan hanya pada peraturan-peraturan yang tertulis atau bahan-bahan hukum lain. Dalam penelitian jurnal ini undang-undang yang digunakan adalah Undang-Undang Nomor 5 Tahun 1999 tentang Larangan Praktik Monopoli dan Persaingan Usaha Tidak Sehat serta Undang-Undang Nomor 18 Tahun 1999 tentang Jasa Konstruksi. Untuk penelitian hukum yang bersifat normatif ini, maka penulis akan menggunakan suatu penelitian yang difokuskan untuk mengkaji penelitian hukum positif, dalam hal ini adalah bahan hukum tertulis, khususnya yang berhubungan dengan wewenang KPPU dalam memberikan sanksi terhadap pihak lain pada kasus persekongkolan tender yang tercantum pada peraturan perundang-undangan terkait. Bahan hukum tertulis yang dimaksud adalah undang-undang yang berlaku di Indonesia, khususnya mengenai kewenangan KPPU.

\section{Pendekatan Masalah}

Pendekatan yang akan penulis gunakan dalam penelitian ini adalah pendekatan perundang-undangan (statute approach), yakni dengan menelaah undangundang dan regulasi yang berhubungan dengan isu hukum yang sedang dibahas. Terkait penelitian ini bersifat akademis, maka penulis perlu mencari ratio legis dan dasar ontologis lahirnya Undang-Undang Nomor 5 Tahun 1999 tentang Larangan Praktik Monopoli dan Persaingan Usaha Tidak Sehat. Selain itu dalam penelitian ini penulis menggunakan pendekatan case approach, yakni melakukan telaah terhadap kasuskasus terkait yang telah memiliki kekuatan hukum tetap oleh putusan pengadilan. Pokok kajian dalam pendekatan ini ialah decidendi atau reasoning sebagai referensi bagi penyusunan argumentasi dalam pemecahan isu hukum. ${ }^{6}$

Selain itu, studi yang digunakan oleh penulis untuk mempermudah pemahaman masalah adalah sumber dari selain perundang-undangan melainkan juga sumber dari studi kepustakaan. ${ }^{7}$ Studi kepustakaan ditandai dengan kegiatan mencari literatur yang ada kaitannya dengan inti pembahasan, khususnya tentang persekongkolan tender.

${ }^{6}$ Peter Mahmud Marzuki, Penelitian Hukum, Revisi. (Surabaya: Kencana Prenada Media Group, 2015), Hlm 133134.

${ }^{7}$ Prasetijo Riyadi Dkk, 5 Langkah Mudah Menyelesaikan Skripsi \& Tesis Hukum (Surabaya: Perwira Media Nusantara, 2015).

\section{Bahan Hukum}

Bahan hukum yang digunakan terdiri atas bahan hukum primer, bahan hukum sekunder, serta bahanbahan non hukum :

a. Bahan hukum primer yang digunakan pada proposal penelitian hukum ini adalah peraturan perundangundang terkait dengan permasalahan yang akan penulis bahas diantaranya Undang-Undang Nomor 5 Tahun 1999 tentang Larangan Praktik Monopoli dan Persaingan Usaha Tidak Sehat, Undang-Undang Nomor 18 Tahun 1999 tentang Jasa Konstruksi dan peraturan-peraturan menteri terkait serta Putusan Komisi Pengawas Persaingan Usaha Nomor: 15/KPPU-L/2007

b. Dalam penelitian ini penulis juga menggunakan bahan-bahan non hukum, misalnya adalah buku teks, jurnal hukum, pendapat para pakar mengenai persekongkolan tender, seperti halnya dalam pengadaan barang dan jasa oleh pemerintah atau halhal selain hukum yang keseluruhannya berkaitan erat dengan pokok permasalahan yang akan penulis bahas.

\section{HASIL DAN PEMBAHASAN \\ Pendekatan Yuridis Persekongkolan Tender}

Untuk mewujudkan iklim tender yang kompetitif maka peserta tender harus lebih dari dua pelaku usaha. Dengan lebih banyaknya peserta tender maka akan memberikan pilihan yang lebih banyak pula dalam penawaran harga dari proyek yang diadakan. Sebaliknya, keterbatasan piihan tentunya sangat merugikan pengada barang/jasa. Karena pada dasarnya tujuan dari pelaksanaan tender ialah mendapakan harga terendah dengan kualitas terbaik dari spesifikasi yang diinginkan. ${ }^{8}$ Namun tak jarang pada prakteknya terdapat pula kecurangan yang dilakukan oleh para pelaku usaha peserta tender dengan panitia lelang yang dapat merugikan pemerintah maupun pelaku usaha lain yang tidak dapat berpartisipasi dalam pengadaan barang dan/ jasa. Bentuk kerjasama baik antara pelaku usaha peserta tender satu dengan lainnya maupun antara pelaku usaha peserta tender dengan panitia tender disebut sebagai persekongkolan. Persekongkolan antar pelaku usaha peserta tender merupakan bentuk persekongkolan vertikal. Sedangkan persekongkolan antara pelaku usaha peserta tender dengan panitia tender ialah bentuk persekongkolan horizontal.

Yakub Adi dalam karya tulisnya "Analisis Terhadap Pasal 22 Undang-Undang No. 5 Tahun 1999 dan Karakteristik Putusan KPPU tentang Persekongkolan Tender" Yakub Adi Kristiano mengklasfikasikan ruang lingkup tender terbagi menjadi tiga. Pertama, tawaran mengajukan harga (terendah)

${ }^{8}$ Y Budianto Monareh, "Masalah Persekongkolan Tender Dalam Persaingan Usaha- Studi Kasus Putusan KPPU No.35/KPPU-1/2010 Dalam Proyek Donggi Senoro," Universitas Indonesia (2011), hlm 30. 
untuk memborong suatu pekerjaan. Kedua, tawaran mengajukan harga (terendah) untuk mengadakan barangbarang. Ketiga, tawaran mengajukan harga (terendah) untuk menyediakan jasa. Tawaran yang dilakukan oleh pemilik kegiatan/proyek lebih baik diserahkan pihak lain yang mempunyai kapabilitas untuk melaksanakan proyek/kegiatan tersebut demi memperoleh keefektifan dan keefisienan terhadap proyek yang diadakan. ${ }^{9}$

Ditinjau dari pasal 22 Undang-Undang Nomor 5 Tahun 1999 yang menyatakan " Pelaku usaha dilarang bersekongkol dengan pihak lain untuk mengatur atau menentukan pemenang tender sehingga dapat mengakibakan persaingan usaha tidak sehat". Maka dapat diketahui adanya unsur-unsur sebagai berikut: pelaku usaha, bersekongkol, pihak lain, mengatur dan menentukan pemenang tender, dan unsur persaingan usaha tidak sehat.

Mengenai penjelasan unsur pelaku usaha dapat dilihat definisinya ada pasal 1 angka 5 Undang-Undang No 5 Tahun 1999 yakni orang perorangan atau badan usaha, baik yang berbentuk badan hukum atau bukan badan hukum yang didirikan dan berkedudukan atau melakukan kegiatan dalam wilayah hukum negara Republik Indonesia, baik sendiri maupun bersama-sama melalui perjanjian, menyelenggarakan berbagai kegiatan usaha dalam bidang ekonomi. Sedangkan yang dimaksud dengan bersekongkol berdasarkan pedoman pasal 22 Undang-Undang No 5 Tahun 1999 ialah kerjasama yang dilakukan oleh pelaku usaha dengan pihak lain atas inisiatif siapapun dengan cara apapun dalam upaya memenangkan peserta tender tertentu. Definisi lain dari persekongkolan juga terdapat pada pasal 1 angka 8 Undang-Undang No. 5 Tahun 1999 yang menyebutkan persekongkolan atau konspirasi usaha adalah bentuk kerjasama yang dilakukan oleh pelaku usahadengan pelaku usaha lain dengan maksud untuk menguasai pasar bersangkutan bagi kepentingan pelaku usaha yang bersekongkol. Definisi dari unsur pihak lain dalam persekongkolan tender ialah para pihak yang terlibat dalam proses tender yang melakukan persekongkolan tender baik pelaku usaha sebagai peserta tender dana tau subyek hukum lainnya yang terkait dengan tender tersebut. Unsur mengatur dan menentukan pemenang tender telah jelas bahwa haruslah ada salah satu dari peserta tender yang melakukan persekongkolan yang dimenangkan. Dan yang terakhir ialah unsur persaingan usaha tidak sehat yang telah didefinisikan pada pasal 1 angka 6 Undang-Undang No. 5 Tahun 1999. Bahwa persaingan usaha yang tidak sehat ialah persaingan antara pelaku usaha dalam menjalankan kegiatan produksi dan atau pemasaran barang dan atau jasa yang dilakukan degan cara tidak jujur atau melawan hukum atau menghambat persaingan usaha.

${ }^{9}$ Yakub Adi Kristianto, "Masalah Persengkongkolan Tender Dalam Persaingan Usaha- Studi Kasus Putusan KPPU No.35/KPPU-1/2010," Yayasan Pengembangan Hukum Bisnis Jakarta 24.4 (2005).
Sedangkan menurut Yakub Adi Kristiano terdapat beberapa unsur yang apabila terpenuhi maka suatu kegiatan tender dapat dikatakan terdapat bentuk persekongkolan. Unsur-unsur tersebut meliputi. Adanya dua atau lebih pelaku usaha, adanya kerjasama untuk melakukan persekongkolan dalam tender, adanya tujuan untuk menguasai pasardan adanya usaha untuk mengatur/ menentukan pemenang tender serta mengakibatkan persaingan usaha tidak sehat. ${ }^{10}$

Terdapat dua pendekatan yuridis dalam penegakan Undang-Undang Anti Monopoli dan Persaingan Usaha Tidak Sehat. Yang pertama ialah pendekatan rule of reason, dimana dalam menilai bahwa suatu perbuaan atau perjanjian yang dilakukan oleh pelaku usaha tersebut dikatakan melanggar hukum apabila efek/ dampaknya menyebabkan kerugian bagi pelaku usaha lain maupun konsumen. Dalam bukunya Hukum Persaingan Usaha - Filosofi, Teori dan Implikasi Penerapannya di Indonesia yang dikutip oleh I Made Sarjana dalam jurnalnya, Johny Ibrahim mengungkapkan bahwa pendekatan rule of reason pertama kali dicetuskan oleh hakim dalam perkara Mitchel v Reynolds pada tahun 1711 di Amerika. Hakim memutuskan bahwa hanya perjanjian yang tidak masuk akal lah yang dianggap melanggar hukum, sehingga tidak semua perjanjian yang menghalangi perdagangan dapat dikatakan melanggar hukum. Doktrin tersebut menjadi terkenal dan mengakar pada tradisi common law. Sehingga menjadi suatu yurisprudensi yang digunakan oleh Hakim Agung White dalam memutuskan perkara Standard Oil vs United States yang menjadi putusan perkara penting (landmark decision). ${ }^{11}$

Pendekaan yuridis yang kedua ialah per se illegal, yakni suatu perjanjian ataupun perbuatan dianggap melanggar hukum asalkan melanggar norma yang telah detapkan dalam perauran perundang-undangan. Dalam pendekatan ini tidak diperlukan lagi pembuktian lebih lanjut apakah perjanjian atau perbuatan tersebut memiliki dampak negatif ataupun merugikan pihak konsumen serta pelaku usaha lain dipasar yang bersangkutan.

Unsur terakhir dalam pasal 22 yang menyatakan "...dapat mengakibatkan persaingan usaha tidak sehat" mengindikasikan bahwa pendekatan yuridis pada pasal ini ialah pendekatan rule of reason sebagaimana telah diuraikan dalam penjelasan sebelumnya. Diperkuat dengan pernyataan yang tertuang pada pedoman pasal 22 tentang larangan persekongkolan tender dalam sub-bab mengenai hal-hal yang perlu diperhatikan untuk menganalisa adanya persekongkolan dalam suatu tender. Disana menyebutkan bahwa dalam prosesnya, apakah persekongkolan tender tersebut terdapat upaya yang tidak jujur atau cara yang melawan hukum. Sehingga perilaku tersebut bersifat rule of reason, yaitu bahwa

${ }^{10}$ Loc. Cit, hlm 47

${ }^{11}$ I Made Sarjana, "Analisis Pendekatan Ekonomi Dalam Hukum Persaingan Usaha," no. 1 (2003): hlm 6-8. 
suatu tindakan memerlukan pembuktian dalam menentukan telah terjadinya pelanggaran terhadap persaingan usaha yang sehat.

Hampir semua istilah persekongkolan di kegiatan masyarakat memiliki konotasi yang negatif. Sebagaimana didefinisikan dalam Kamus Besar Bahasa Indonesia bahwa kata dasar dari persekongkolan ialah sekongkol yang artinya orang yang berkomplot melakukan kejahatan, kecurangan dan sebagainya. Persekongkolan sendiri diartikan sebagai bersekutu, bersepakat melakukan kejahatan. ${ }^{12}$

Ditambah lagi dengan adanya unsur "mengatur dan menentukan pemenang tender" pada pasal tersebut, bila pemenang tender telah diatur dan ditentukan oleh para pelaku persekongkolan, tentu saja tidak akan ada persaingan yang kompetitif dan adil.

Maka kaitannya dengan persekongkolan yang selalu berkonotasi negatif dan upaya dalam memenangkan salah satu peserta tender dengan cara-cara tertentu, seharusnya dalam persekongkolan tender, pendekatan yuridis yang digunakan ialah pendekatan per se illegal.

\section{Wewenang KPPU dalam Memberikan Sanksi Terhadap Pihak Lain}

Komisi Pengawas Persaingan Usaha aau KPPU merupakan lembaga independen yang didirikan oleh negara untuk mengawasi pelaksanaan Undang-Undang Nomor 5 Tahun 1999 entang Larangan Praktik Monopoli dan Persaingan Usaha Tidak Sehat. Dimana komisioner dalam KPPU berjumlah 9 orang dan diangkat oleh Presiden berdasarkan pertimbangan dari DPRRI. Dalam mengemban tugasnya KPPU bertanggung jawab secara langsung pada Presiden.

Menurut Yuliana Juwita dalam karya tulisnya, KPPU ialah suatu organ khusus yang memiliki tugas ganda. Yakni untuk menciptakan dan memelihara iklim persaingan usaha yang sehat, serta untuk menciptakan ketertiban dalam persaingan usaha. Meskipun KPPU merupakan lembaga yang memiliki fungsi penegakan hukum dalam hukum persaingan usaha, namun KPPU bukanlah lembaga peradilan khusus persaingan usaha. ${ }^{13}$

Sejak berdirinya KPPU di tahun 2000, penyelesaian kasus tentang persekongkolan tender telah banyak diselesaikan oleh KPPU. Banyaknya persekongkolan tender secara vertikal dapat dilihat dari putusan-putusan yang telah dipuuskan oleh KPPU. Seperti yang telah penulis jelaskan sebelumnya, bahwa persekongkolan tender vertikal ialah persekongkolan/ kerjasama yang dilakukan oleh pelaku usaha dengan panitia tender. Bahkan sepanjang tahun 2013, kasus

\footnotetext{
${ }^{12}$ Op.cit, Asmah.

${ }^{13}$ Riski Dysas Prabawani Dkk, "Analisis Yuridis Penegakan Hukum Persengkongkolan Tender Menurut Undang-Undang Nomor 5 Tahun 1999 Tentang Praktik Larangan Monopoli Dan Persaingan Usaha Tidak Sehat," Privat Law V (2017), hlm 80.
}

persekongkolan tender mendominasi putusan perkara pada KPPU. ${ }^{14}$

Sebagai gambaran, penulis mengambil salah satu kasus yakni kasus pembangunan pasar modern pada kota Prabumulih. Bermula pada akhir bulan Maret 2006 Hak Guna Bangunan (HGB) pedagang pasar tradisional Prabumulih berakhir dan hanya sekitar $15 \%$ pedagang saja yang belum melunasi sewa sehingga serifikatnya masih menjadi agunan bank BRI. Hal tersebut membuat Walikota dan Wakil Walikota berencana membangun sebuah Pasar Modern Prabumulih. Wakil Walikota Prabumulih yang saat itu sekaligus menjabat sebagai Pelaksana Tugas (Plt) Walikota berdasarkan pertimbangan dari Kepala Bagian Hukum, mencetuskan ide untuk mengadakan tender guna menarik investor. Sebelum tender dibuka, diketahui bahwa Ferry Soelisthio yang merupakan Direktur Utama PT Prabu Makmur melakukan presentasi mengenai rencana pembangunan Pasar Modern Prabumulih di DPRD dan di Pemerintah Daerah Prabumulih yang ketika itu dihadiri oleh Wakil Walikota. Disamping itu ia juga telah menjual rencana kios-kios kepada para pedagang di wilayah Prabumulih dan Palembang dengan rekening bank mandiri atas nama PT. Putra Prabu meskipun belum ada AMDAL untuk pembangunan Pasar Modern Prabumulih.

Hingga pada tanggal 10 Oktober 2006 pegumuman pelelangan umum tentang undangan kepada para penyedia barang/jasa oleh Panitia Pengadaan Barang/ Jasa Setda Kota Prabumulih yang akan dibuka mulai tanggal 11-30 Oktober 2006. Pada anggal 31 Oktober 2006 dilakukan pemasukan serta pembukaan dokumen penawaran sehingga diketahui terdapat 7 perusahaan yang mengikuti lelang tersebut yakni: PT. Prabu Makmur, PT Sungai Musi Perdana, PT. Putra Prabu , PT. Makasar Putra Perkasa, PT. Alexindo Sekawan, PT. Lematang Sentana dan PT. Tiga Reka Persada. Namun seluruh dokumen yang dikirimkan oleh para peserta lelang tersebut tidak ada yang sah sehingga Panitia lelang menyatakan bahwa lelang pembangunan Pasar Modern Prabumulih gagal.

Pengumuman tentang lelang umum pembangunan Pasar Modern Prabumulih dilakukan kembali pada tanggal 3 November 2006 oleh Panitia lelang. Kali ini pengumuman lelang dimuat pula pada Harian Sriwijaya Post, Media Indonesia dan papan pengumuman guna mendapatkan peserta lelang yang lebih banyak. Proses pemberian dokumen penawaran dimulai dari tanggal 617 November 2006. Namun ketika dilakukan pembukaan terhadap dokumen penawaran pada tanggal 20 November 2006, diketahui bahwa yang menjadi peserta lelang ialah 7 perusahaan yang sama dengan yang menjadi peserta lelang pada lelang sebelumnya. Perama kali yang digugurkan dalam proses adminisrasi kali ini ialah PT. Putra Prabu karena terdapat ketidaksesuaian antara angka dan huruf dalam dokumen

${ }^{14}$ Op.cit, Adifyan Rahmat Asga, Hlm 3. 
penawarannya. Selanjunya pada anggal 21 November 2006, Panitia lelang menggugurkan 4 peserta lainnya karena tidak melampirkan beberapa dokumen yang dipersyaratkan. Keempat peserta lelang itu ialah: PT. Tiga Reka Persada, PT. Alexindo Sekawan, PT Makassar Putra Perkasa, dan PT. Lentang Sentana. Sehingga setelah dilakukan evaluasi teknis pada tanggal 22 November 2006 terhadap 2 peserta lelang yang tersisa yakni PT Prabu Makmur dan PT. Sungai Musi Perdana dinyatakan lolos. Kemudian dilakukan evaluasi harga pada tanggal 23 November 2006 dengan hasil PT Prabu Makmur memberikan harga penawaran lebih rendah dengan kontribusi lebih besar dibandingkan PT Sungai Musi Perdana. Sehingga pada tanggal 28 November 2006 Panitia lelang mengusulkan PT Prabu Makmur sebagai pemenang lelang kepada Pengelola Barang/Jasa kegiatan pembangunan Mall Kota Prabumulih.

Dalam kasus tersebut majelis komisi memberikan amar putusan. Pertama, Menyatakan bahwa terlapor I-V dan terlapor VII terbukti secara sah dan meyakinkan telah melanggar pasal 22 Undang-Undang Nomor 5 Tahun 1999 tentang Larangan Praktek Monopoli dan Persaingan Usaha Tidak Sehat. Kedua, Menyatakan bahwa terlapor VI tidak terbukti melanggar pasal 22.

Ketiga, Membatalkan hasil lelang pembangunan Mall di Kota Prabumulih tahun 2006, Keempat, Menghukum terlapor I-V untuk tidak mengikuti tender di seluruh instansi Pemerintah Kota Prabumulih selama 2 tahun setelah putusan ni memiliki kekuatan hukum tetap dan kelima, Menghukum terlapor I-V untuk membayar denda masing-masing sebesar 1.000.000.000 (Satu Milyar Rupiah) apabila melanggar butir 4 yang harus disetorkan pada Kas Negara sebagai setoran pendapatan denda pelanggaran di bidang persaingan usaha.

Dalam kasus persekongkolan tender, yaitu pelanggaran terhadap Pasal 22 Undang-Undang Larangan Praktik Monopoli dan Persaingan Usaha Tidak Sehat dapat dikenakan sanksi administratif maupun hukuman pidana. Sanksi administratif diatur dalam Pasal 47. Sanksi administratif terhadap pelaku usaha yang melanggar ketentuan Pasal 22 dapat berupa. Pertama, perintah kepada pelaku usaha untuk menghentikan kegiatan yang terbukti menimbulkan praktik monopoli danatau menyebabkan persaingan usaha tidak sehat dan atau menyebabkan persaingan usaha tidak sehat dan/atau merugikan masyarakat (Pasal 47 ayat (2) huruf c); dan atau. Kedua, Pengenaan pembayaran ganti rugi (Pasal 47 ayat (2) huruf f); dan/atau. Ketiga, pengenaan denda serendah-rendahnya Rp1.000.000.000,00 (satu milyar rupiah) dan setinggi-tingginya Rp25.000.000.000,00 (dua puluh lima miliar rupiah) (Pasal 47 ayat (2) huruf g).

Selain sanksi administratif terdapat juga sanksi pidana pokok sebagaimana yang diatur dalam Pasal 48 serta pidana tambahan sebagaimana diatur dalam pasal 49 Undang-Undang Larangan Praktik Monopoli dan
Persaingan Usaha Tidak Sehat, yaitu berupa. Pertama, pidana denda serendah-rendahnya Rp5.000.000.000,00 (lima milyar rupiah) dan setinggi-tingginya Rp25.000.000.000,00 (dua puluh lima milyar rupiah), atau pidana kurungan pengganti denda selama-lamanya 5 (lima) bulan (Pasal 48 ayat (2); atau, Kedua, pidana denda serendah-rendahnya Rp1.000.000.000,00 (satu milyar rupiah) dan setinggi-tingginya Rp5.000.000.000,00 (lima milyar rupiah) atau pidana kurungan pengganti denda selamalamanya 3 (tiga) bulan (Pasal 48 ayat (3), dalam hal pelaku usaha menolak menyerahkan alat bukti yang diperlukan dalam penyelidikan dan/atau pemeriksaan atau menolak diperiksa, menolak memberikan informasi yang diperlukan dalam penyelidikan danatau pemeriksaan, atau menghambat proses penyelidikan dan atau pemeriksaan sebagaimana dimaksud dalam Pasal 41 ayat (1) dan (2).

Pasal 49 Undang-Undang Larangan Praktik Monopoli dan Persaingan Usaha Tidak Sehat yang berupa, Pasal Pencabutan izin usaha; atau Larangan kepada pelaku usaha yang telah terbukti melakukan pelanggaran terhadap undang-undang ini untuk menduduki jabatan direksi atau komisaris sekurangkurangnya 2 (dua) tahun dan selama-lamanya 5 (lima) tahun; atau Penghentian kegiatan atau tindakan tertentu yang menyebabkan timbulnya kerugian pada pihak lain.

Berdasarkan pasal 36 huruf I tentang tugas dan wewenang KPPU dapat diketahui bahwa meskipun KPPU memiliki wewenang untuk menegakkan hukum dalam bidang persaingan usaha, namun sanksi yang dapat dijatuhkan oleh KPPU hanya sebatas sanksi adminisrasi saja. Sehingga KPPU tidak berwenang dalam menjatuhkan sanksi perdata maupun pidana, dimana yang berwenang dalam hal tersebut ialah lembaga peradilan umum. Pemberian sanksi adminisratif oleh KPPU dalam putusan No. 15/KPPU-L/2007 telah sesuai dengan kewenangan yang dimiliki oleh KPPU.

Sehingga dalam amar putusan yang dikeluarkan KPPU hanya menyebutkan sanksi pada pelaku usaha. Meskipun dalam persekongkolaan tender pihak yang bertanggung jawab bukan hanya dari pelaku usaha sebagai peserta tender, namun juga panitia tender ikut serta dalam memenangkan salah satu pelaku persekongkolan. Sebagaimana disebutkan dalam unsur pihak lain yang dimaksud pada pasal 22 UndangUndang No 5 Tahun 1999 yang disebutkan dalam pedoman pasal tersebut yakni para pihak yang terlibat dalam proses tender yang melakukan persekongkolan tender baik pelaku usaha sebagai peserta tender dana tau subyek hukum lainnya yang terkait dengan tender tersebut.

Ketentuan mengenai pasal 47, pasal 48 dan pasal 49 diatas secara khusus hanya ditujukan bagi pelaku usaha yang terbukti melanggar ketentuan undangundang antimonopoli tentang larangan persekongkolan tender. Sedangkan panitia/ penyelenggara tender atau pun pejabat pemerintah serta politikus yang terlibat 
dalam kegiatan persekongkolan tender dengan pelaku usaha tidak dapat dikenakan sanksi sebagaimana diatur dalam ketiga pasal tersebut oleh KPPU. Karena tidak adanya wewenang yang dimiliki oleh KPPU dalam menjerat pihak yang disebut dengan pihak lain, meskipun pejabat yang menjadi panitia tender tersebut telah terbukti terlibat dalam persekongkolan tender. ${ }^{15}$

Amar putusan yang dikeluarkan KPPU dengan tanpa menghukum panitia tender yang turut serta melakukan persekongkolan dikarenakan dalam UndangUndang No. 5 tahun 1999 sendiri memang tidak memberikan sanksi adminisratif terhadap pihak panitia lelang. Akan tetapi panitia lelang dapat dikenakan sanksi pidana oleh lembaga peradilan umum dalam kaitannya pelanggaran terhadap pasal 22 sebagaimana diatur dalam pasal 48 ayat (2).

Berkaitan dengan denda apabila para pelaku usaha terlapor yang telah terbukti melakukan pelanggaran terhadap pasal 22 Undang-Undang No. 5 Tahun 1999 melanggar putusan yang telah ditetapkan oleh KPPU butir ke-4 dengan memberikan denda masing-masing sebesar 1.000.000.000, dibandingkan dengan keuntungan para pelaku usaha terlapor bila memenangkan tender maka nominal tersebut terlalu kecil. Sebagaimana didalam putusan No. 15/KPPUL/2007 diketahui bahwa para pelaku usaha terlapor dapat berkontribusi dalam pembangunan hingga sebesar 4.000.000.000 (empat milyar rupiah) atau empat kali lipat dari besarnya denda pelanggaran yang akan dijatuhkan maka hal tersebut tidak akan memberikan efek jera bagi para pelaku usaha terlapor maupun para pelaku usaha lain yang akan melakukan tindakan curang serupa.

Hal lain yang mengganjal dalam kasus tender diatas yakni adanya induk perusahaan dan anak perusahaan yang mengikuti tender yang sama. Semestinya terdapat larangan terhadap perusahaan terafiliasi mengikuti tender yang sama dalam waku yang sama. Sebagaimana rumusan pasal 17 ayat(6) UndangUndang Nomor 18 Tahun 1999 "Badan-badan usaha yang dimiliki oleh suatu atau kelompok orang yang sama atau berada pada kepengurusan yang sama tidak boleh mengikuti pelelangan untuk satu pekerjaan konstruksi secara bersamaan". Diketahui dalam bukti bahwa PT. Putra Prabu merupakan anak perusahaan dari PT. Prabu Makmur yang menjadi pemenang dalam tender pembangunan Pasar Modern Prabumulih.

\section{SIMPULAN}

Pendekatan yuridis dalam pembuktian persaingan usaha tidak sehat dibagi menjadi dua yakni rule of reason dan per se illegal. Pendekatan rule of reason ialah pendekaan yuridis yang harus melihat dampak atau akibat-akibat yang dimunculkan dari perjanjian maupun kegiatan yang dilakukan olehpelaku usaha. Sedangkan pendekatan per se illegal ialah pendekatan yang

${ }^{15}$ Op.cit, L Budi Kagramanto
Sedangkan Per Se Illegal adalah rumusan pasal mengenai perbuatan tertentu yang dilarang untuk dilakukan, di mana perbuatan tersebut sudah dapat terbukti dilakukan dan dapat di proses secara hukum tanpa harus menunjukan akibat-akibat atau kerugian yang secara nyata terhadap persaingan. Dalam pasal 22 tentang larangan persekongkolan tender menggunakan pendekatan rule of reason dimana KPPU harus melihat adanya persaingan usaha yang tidak sehat sebagai akibat dari persekongkolan yang dilakukan oleh para pelaku usaha yang bersekongkol.

Ketentuan dalam pasal 47, 48 dan 49 hanya dapat diterapkan pada para pelaku usaha yang terbukti melakukan persekongkolan tender. Sedangkan para pihak yang melakukan persekongkolan tender terdapat pula pihak lain yang dalam kasus ini ialah pejabat instansi pemerintah yang menjadi panitia/ penyelenggara lelang. Tidak adanya wewenang KPPU sebagai pengemban amanah dari undang-undang sebagai pengawas dan penegak Undang-Undang Nomor 5 Tahun 1999 unuk menjerat pihak lain, dapat menghambat penegakan hukum antimonopoli dan persaingan usaha tidak sehat.

Persekongkoln tender merupakan suatu kegiatan yang berupaya untuk memenangkan tender salah satu peserta yang bersekongkol. Dengan demikian maka tidak dicapainya iklim persaingan usaha yang sehat serta menimbulkan kerugian-kerugian bagi pelaku usaha pesaing maupun pemerintah/ penyelenggara tender. Maka seharusnya norma dalam pasal 22 yang mengatur mengenai larangan persekongkolan tender menggunakan pendekatan yuridis per se illegal. Yakni ketika perbuatan tersebut terbukti melanggar ketentuan yang telah ada dalam peraturan perundang-undangan maka para pihak yang melakukan persekongkolan dapat dijatuhi sanksi tanpa melihat ada/ tidaknya dampak persaingan usaha tidak sehat.

Untuk mewujudkan iklim persaingan usaha yang sehat, KPPU sebagai lembaga yang menegakkan Undang-Undang Nomor 5 Tahun 1999 tentang Larangan Praktek Monopoli dan Persaingan Usaha Tidak Sehat sepatutnya diberi wewenang untuk menjerat atau memberikan sanksi terhadap siapa saja yang melanggar ketentuan dalam peraturan undang-undang tersebut, termasuk pejabat dari instansi pemerintahan sekalipun.

\section{DAFTAR PUSTAKA}

\section{Buku dan Jurnal}

Adifyan Rahmat Asga dan Ditha Wiradiputra. 2012, "Analisa Kedudukan Panitia Tender Dalam Persekongkolan Tender Secara Vertikal (Studi Kasus Putusan KPPU Nomor 04/KPPU-L/2013)." Universitas Indonesia: 2.

Dkk, Prasetijo Riyadi, 2015, 5 Langkah Mudah Menyelesaikan Skripsi \& Tesis Hukum. Surabaya: Perwira Media Nusantara.

Dkk, Riski Dysas Prabawani, 2017, “Analisis Yuridis Penegakan Hukum Persengkongkolan Tender 
Menurut Undang-Undang Nomor 5 Tahun 1999

Tentang Praktik Larangan Monopoli Dan Persaingan Usaha Tidak Sehat." Privat Law V.

Kagramanto, L Budi, 2007, "Komparasi Pengaturan

Tender Di Indonesia Dan Jepang Dalam

Prespektif Hukum Persaingan Usaha." Era

Hukum.

Keintjem, Enrico Billy, 2016, “Tinjauan Yuridis Praktek Persekongkolan Yang Tidak Sehat Dalam Tender Proyek Menurut Undang-Undang Nomor 5 Tahun 1999." Lex Administrantum 4.4.

Kristianto, Yakub Adi, 2005, "Masalah Persengkongkolan Tender Dalam Persaingan Usaha- Studi Kasus Putusan KPPU No.35/KPPU1/2010." Yayasan Pengembangan Hukum Bisnis Jakarta 24.4 .

Marzuki, Peter Mahmud, 2015, Penelitian Hukum. Revisi. Surabaya: Kencana Prenada Media Group.

Monareh, Y Budianto, 2011, "Masalah Persekongkolan Tender Dalam Persaingan Usaha- Studi Kasus Putusan KPPU No.35/KPPU-1/2010 Dalam Proyek Donggi Senoro." Universitas Indonesia.

Sarjana, I Made, 2003, "Analisis Pendekatan Ekonomi Dalam Hukum Persaingan Usaha," no. 1 : 6-8.

Sudarsono, 1992, Kamus Hukum. Jakarta: Rineka Cipta. Supianto, 2013, "Pendekatan Per Se Illegal Dan Rule Of Reason Dalam Hukum Persaingan Usaha Di Indonesia." Jurnal Rechtens 2.

\section{Undang-Undang}

Undang-Undang Nomor 5 Tahun 1999 tentang Larangan Praktek Monopoli dan Persaingan Usaha Tidak Sehat

Undang-Undang Nomor 18 Tahun 1999 tentang Jasa Konstruksi 